\title{
Identifikasi dan Karakterisasi Aktivitas Ekstrak Kasar Enzim Lipase Isolat Bakteri Lipolitik Lptk 19 Asal Tempe Biji Karet
}

\author{
Cico Jhon Karunia Simamora ${ }^{1}$, Sukmawati Sukmawati ${ }^{2}$ \\ ${ }^{1}$ Universitas Tanjungpura Pontianak \\ ${ }^{2}$ Universitas Muhammadiyah Sorong \\ *chicosimamora@gmail.com
}

\begin{abstract}
Abstrak
Lipase adalah enzim yang larut dalam air yang memiliki kemampuan untuk menghidrolisis triasilgliserol untuk melepaskan asam lemak bebas dan gliserol. Tujuan utama dalam penelitian ini adalah karakterisasi aktivitas ekstrak kasar lipase dan identifikasi isolat lipolitik potensial LpTk 19. Pelaksanaan penelitian meliputi peremajaan isolat, uji kualitatif yang diindikasikan dengan terbentuknya zona bening pada medium LAOR, serta uji kuantitatif aktivitas enzim lipase, uji aktivitas spesifik enzim, dan identifikasi biokimia isolat bakteri LpTk 19. Hasil uji kualitatif isolat bakteri LpTk 19 pada umur 48 jam, inkubasi suhu ruang mencapai 90,59\%. Nilai aktivitas enzim tertinggi didapatkan pada umur inkubasi 60 jam sebesar 487,5 U/mL, kadar protein tertinggi pada jam ke-48 sebesar $12,4 \mathrm{mg} / \mathrm{mL}$, dan aktivitas spesifik enzim tertinggi pada inkubasi 60 jam sebesar 325,0 U/mg. Identifikasi biokimia menunjukkan bahwa diketahui isolat bakteri LpTk 19 termasuk dalam golongan bakteri Gram positif, yang termasuk family Bacillaceae, dengan jenis Bacillus sp.
\end{abstract}

Kata kunci: Bacillus, lipase, lipolitik, tempe, waktu produksi

\section{PENDAHULUAN}

Lipase (Triacylglycerol Lipases, EC 3.1.1.3) adalah enzim larut air yang memiliki kemampuan untuk menghidrolisis triasilgliserol menjadi asam lemak bebas (Sirisha et al., 2010). Lipase merupakan kelompok utama biokatalis yang memiliki aplikasi bioteknologi yang luas. Lipase telah diisolasi dan dimurnikan dari jamur, ragi, bakteri, tumbuhan dan sumber hewani (Joseph et al., 2008). Dari semua ini, lipase dari bakteri yang lebih ekonomis dan stabil (Snellman et al., 2002). Beberapa genus bakteri penghasil lipase antara lain adalah Bacillus, Pseudomonas dan Burkholderia (Pramiadi et al., 2014).

Lipase bakteri diaplikasikan secara luas dalam industri seperti industri makanan, susu, deterjen, tekstil, kosmetik dan farmasi (Sirisha et al., 2010). Saat ini lipase bakteri sangat diminati karena aplikasi industri yang potensial. Produksi lipase secara komersial telah dilakukan di beberapa negara maju. Namun, biaya yang dikeluarkan untuk mengimpor enzim produksi luar negeri sangat tinggi, sehingga biaya produksi lebih mahal dan berdampak pada naiknya harga produk-produk hasil olahannya.

Indonesia merupakan negara tropis yang memiliki keanekaragaman mikroorganisme yang tinggi. Beberapa jenis mikroorganisme menghasilkan lipase yang berpotensi untuk dimanfaatkan pada industri. Untuk itu, diperlukan penelitian yang mengembangkan lipase khususnya yang bersumber dari mikroorganisme. Aplikasi 
industri memerlukan kebutuhan lipase yang dapat diproduksi dalam kapasitas besar dan aktivitas yang tinggi dengan biaya produksi yang ekonomis.

Bacillus merupakan salah satu golongan bakteri yang dapat menghasilkan enzim lipase, dan mampu bertahan hidup di berbagai lingkungan yang ekstrim, dengan kandungan nutrisi dan toksik yang berbeda-beda. Kelebihan pemanfaatan enzim asal mikroba adalah kapasitas produksi tinggi yang dapat ditingkatkan dalam skala besar pada ruangan yang relatif terbatas (Suhartono, 1989). Penelitian ini mengkaji isolat bakteri lipolitik LpTK 19 yang dimurnikan dari tempe biji karet dan telah diketahui memiliki kemampuan produksi enzim lipase ekstraseluler. Pelaksanaan penelitian bertujuan untuk identifikasi dan karakterisasi aktivitas spesifik ekstrak kasar enzim lipase asal bakteri lipolitik LpTk 19 dari tempe biji karet.

\section{METODE PENELITIAN}

\section{Alat dan Bahan}

Alat pendukung yang digunakan dalam penelitian ini meliputi Beaker glass, gelas ukur, pipet tetes, pipet mikro, tabung reaksi, rak tabung reaksi, Eppendorf, laminar air flow cabinet, jarum oose, spatula, oven, cawan Petri, shaker, inkubator, autoclave, microtip $1500 \mu \mathrm{L}$, microtip $200 \mu \mathrm{L}$, korek api, neraca analitik, lampu spiritus, dan microsentrifugator.

Bahan yang digunakan meliputi kultur murni isolat bakteri LpTK 19 asal tempe biji karet, medium Nutrient Broth (pepton $5 \mathrm{~g}, \mathrm{NaCl} 5 \mathrm{~g}$ dan beef ekstrak $3 \mathrm{~g} / \mathrm{L}$ ), minyak zaitun, Ammonium Sulfat, media Luria Agar Olive Rhodamine B/LAOR (pepton 1\%, $\mathrm{NaCl} 1 \%$, ekstrak khamir 0,5\%, agar \%, Polyvinil alkohol $2 \%$, akuadest $1000 \mathrm{~mL}$ dan Rhodamine B 0,1\%), aquadest, aluminium foil, tisu, buffer fosfat, $\mathrm{NaOH}$, aseton, etanol, indikator phenolftalein, larutan biuret, BSA dan gum arab.

\section{Prosedur Kerja}

Adapun prosedur kerja dalam penelitian ini dilakukan mulai dari tahap peremajaan isolat hingga identifikasi mikroskopis dan biokimia bakteri.

\section{Peremajaan Isolat}

Isolat bakteri dipindahkan secara aseptik dengan jarum oose 1 loop pada media Nutrien Agar miring yang telah steril autoclave. Bakteri kemudian diinkubasi pada temperatur ruang selama 48 jam.

\section{Uji Kualitatif Aktivitas Lipase}

Uji kualitatif penghasil lipase menggunakan cawan Petri yang berisi medium LAOR (Luria Agar Olive Oil dan Rhodamine B). Kultur diinkubasi pada suhu ruang selama 2 hari. Aktivitas kualitatif lipase esktraseluler ditandai dengan zona bening yang diamati di bawah sinar UV, untuk kemudian diukur indeks zonanya. Indeks lipolitik dinyatakan sebagai nilai perbandingan antara diameter zona bening dengan diameter 


\section{Median Volume 12 Nomor 1 Bulan Februari 2020}

Doi http://doi.org/md.v12i1.371

koloni. Isolat bakteri dengan nilai indeks lipolitik tertinggi dapat disimpulkan sebagai kandidat potensial penghasil lipase ekstraseluler (Gupta et al., 2004).

\section{Uji Kuantitatif Aktivitas Lipase (modifikasi Ghasemi et al., 2011)}

Produksi lipase dilakukan dengan mengkulturkan bakteri dalam $250 \mathrm{~mL}$ Labu Erlenmeyer berisi $50 \mathrm{~mL}$ medium yang terdiri dari $(\mathrm{b} / \mathrm{v})$ : pepton $0,5 \%$, ekstrak ragi $0,5 \%, \mathrm{NaCl} 7 \%, \mathrm{CaCl}_{2}$ 0,005\%, dan minyak zaitun (1\%, diemulsi dengan gum arab $0,5 \%)$, pH 7,5. $50 \mathrm{~mL}$. Selanjutnya media produksi diinkubasi pada suhu ruang dengan kecepatan $150 \mathrm{rpm}, 48$ jam. Sel dipisahkan dengan sentrifugasi pada $4.800 \mathrm{rpm}$ selama 20 menit dan supernatan digunakan sebagai sumber enzim kasar ekstraseluler.

Aktivitas lipase diuji dengan titrasi alkali substrat minyak zaitun. Campuran uji terdiri 2,5 mL minyak zaitun, 3,5 mL buffer fosfat $(0,1 \mathrm{M}$; $\mathrm{pH} 7,0)$ dan $2 \mathrm{~mL}$ enzim kasar yang diinkubasi selama 20 menit pada suhu ruang. Reaksinya dihentikan dengan menambahkan $10 \mathrm{~mL}$ Etanol, dan jumlah asam lemak yang dibebaskan selama inkubasi diukur dengan $0,05 \mathrm{~N} \mathrm{NaOH}$ dan penambahan indikator fenolphthalein. Satu unit aktivitas lipase didefinisikan sebagai jumlah enzim yang dikalibrasi $1 \mathrm{~mol}$ asam lemak bebas per $\mathrm{mL}$ per menit di bawah kondisi pengujian.

\section{Waktu Optimum Produksi Lipase (modifikasi Zusfahair et al., 2010)}

Kultur murni bakteri diinokulasi dalam $10 \mathrm{~mL}$ medium, diinkubasi selama 2 hari dengan pengocokan $150 \mathrm{rpm}$ pada suhu ruang. Medium NB sebanyak $50 \mathrm{~mL}$ diinkubasi selama 5 menit, kemudian ditambah inokulum bakteri $0,5 \mathrm{~mL}$ dengan minyak zaitun sebagai induser $0,5 \mathrm{~mL}$. Selanjutnya dilakukan inkubasi pada suhu $37^{\circ} \mathrm{C}$ sambil dishaker dengan kecepatan $150 \mathrm{rpm}$ selama 0, 12, 24, 36, 48, 60, dan 72 jam lalu diamati aktivitas lipase dan kadar protein yang dihasilkan pada interval waktu tersebut.

\section{Pengukuran Aktivitas Lipase Metode Titrimetri (modifikasi Sirisha et al., 2010)}

Aktivitas lipase diukur dengan metode titrimetri menggunakan substrat minyak zaitun. Minyak zaitun (10\% v/v) diemulsi dengan gum Arab (5\% b/v) dalam $100 \mathrm{~mL}$ buffer fosfat $0,2 \mathrm{M} ; \mathrm{pH} 8,0$. Sebanyak $0,2 \mathrm{~mL}$ enzim ditambahkan pada larutan emulsi dan diinkubasi selama 15 menit pada suhu $37{ }^{\circ} \mathrm{C}$. Reaksi dihentikan dan asam lemak diekstraksi dengan penambahan 2,5 mL larutan aseton:etanol (1:1). JumLah asam lemak yang dibebaskan diperkirakan dengan titrasi dengan $0,05 \mathrm{M} \mathrm{NaOH}$ menggunakan indikator phenolftalein. Satu unit enzim didefinisikan sebagai jumlah enzim yang dibutuhkan untuk menghidrolisis mol dari asam lemak.

Unit aktivitas lipase $=\frac{V \mathrm{NaOH} \text { sampel }-\mathrm{V} \mathrm{NaOH} \text { kontrol }}{\text { Volume enzim }} \times 100 \%$ (Lestari et al., 2009).

\section{Penentuan Kadar Protein}

Kadar protein ditentukan dengan metode Lowry yang dimodifikasi. Pengukuran kadar protein menggunakan Bovine Serum Albumine (BSA) sebagai standar protein murni. Taraf konsentrasi standar protein yang digunakan meliputi yaitu 0-1000 mg/L. 


\section{Median Volume 12 Nomor 1 Bulan Februari 2020}

Doi http://doi.org/md.v12i1.371

Sebanyak 0,1 mL sampel dimasukkan ke dalam tabung reaksi kemudian dilarutkan di dalam $10 \mathrm{~mL}$. Ambil $1 \mathrm{~mL}$ dan dipindahkan ke tabung reaksi dan tambahkan $1 \mathrm{~mL}$ larutan biuret. Larutan-larutan tersebut dikocok dan dibiarkan pada suhu kamar selama 10 menit. Serapan larutan diukur pada panjang gelombang $480 \mathrm{~nm}$. Kontrol dibuat dengan cara yang sama, menggunakan larutan akuades.

\section{Identifikasi Mikroskopis dan Biokimia Bakteri}

Identifikasi isolat bakteri dilakukan pada biakan yang telah digores pada media Nutrient Agar selama 48 jam dalam suhu ruang. Selanjutnya identifikasi meliputi pengamatan mikroskopis dan uji biokimia yang mengacu pada pedoman identifikasi bakteri (Bergey's Manual Determinative Bacteriology tahun 1948). Identifikasi mikroskopis didahului dengan pewarnaan Gram sel bakteri. Uji biokimia yang dilakukan meliputi uji triple sugar, uji sulfide indol motility, uji penggunaan citrate, uji gula, uji katalase, uji oksidase, uji MacConkey Agar, dan uji balik pada media Sierra yang dilapisi Tween 80 .

\section{HASIL DAN PEMBAHASAN}

\section{Uji Kualitatif Aktivitas Lipase}

Uji aktivitas lipolitik dilakukan pada isolat bakteri LpTK 19 dengan menggunakan media padat LAOR (Luria Agar Olive oil dan Rhodamine B) dapat dilihat pada Gambar 1. Isolat bakteri yang memiliki kemampuan produksi enzim ekstraseluler terbaik adalah isolat yang mampu tumbuh dengan baik pada media substrat yang mengandung lipid (minyak zaitun). Hasil uji kualitatif menunjukkan isolat bakteri LpTK 19 asal tempe biji karet merupakan bakteri lipolitik karena mampu menghasilkan enzim lipase ekstraseluler yang ditandai dengan terbentuknya zona bening mengelilingi koloni bakteri (Tabel 1). Indeks zona tertinggi ditunjukkan setelah inkubasi 48 jam dalam suhu ruang sebesar 90,59\%. Hasil uji kualitatif lipase menggunakan indikator rhodamine B ditunjukkan dengan adanya pendaran memudar di bawah sinar UV setelah sebelumnya diinkubasi suhu ruang selama 48 jam. Hal ini disebabkan karena reaksi Rhodamin B dengan asam lemak membentuk senyawa kompleks dan berpendar di bawah radiasi sinar UV (Dahliaty et al., 2012). Pudarnya pendaran yang terbentuk pada media LAOR disebabkan karena adanya reaksi antara pewarna rhodamine B terhadap asam lemak bebas yang terbentuk dari proses hidrolisis lemak (olive oil) oleh enzim lipase yang dihasilkan oleh bakteri lipolitik (Nur, 2015). Koloni yang menyerap rhodamine B menunjukkan pembentukan koloni yang berwana merah hingga jingga, sementara koloni yang tidak menyerap rhodamine B menunjukkan pembentukan koloni selain warna merah hingga jingga (Suryadi, 2016). Hidrolisis substrat menjadi monogliserida atau digliserida yang berikatan dengan rhodamine B menyebabkan pembentukan lingkaran cahaya jingga di sekitar koloni bakteri pada radiasi UV (Kouker dan Jaeger, 1987). 
Perubahan derajat keasaman akibat akumulasi asam lemak bebas menyebakan terjadinya penumpukan kation yang memicu terbentuknya kompleks uranyl-faty acid yang dapat berpendar jingga hingga merah jika dieksitasi dengan sinar (Kouker dan Jaeger, 1987). Kecerahan dan besarnya zona pendaran di sekitar koloni menunjukkan kemampuan lipolitik dari koloni tersebut. Hasil reaksi hidrolisis antara lipase dengan substrat (minyak zaitun) menghasilkan produk berupa asam lemak bebas. Adanya ikatan kompleks antara rodamin dengan asam lemak bebas tersebut menghasilkan warna merah muda saat diiradiasi di bawah sinar UV (Yin dan Chrost, 2006).

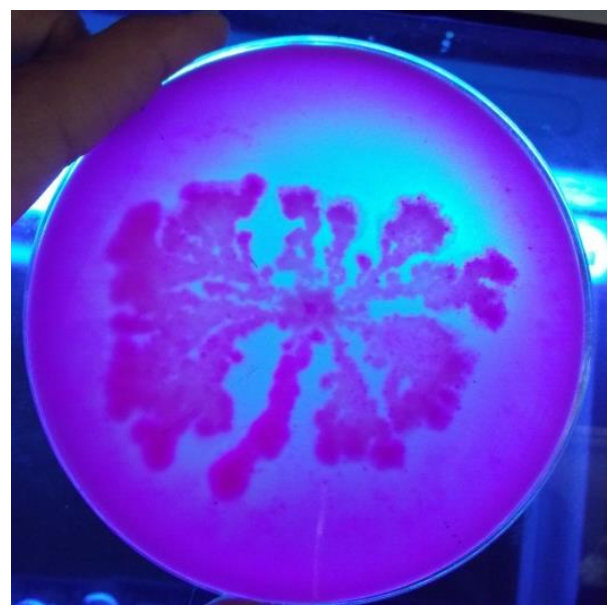

Gambar 1. Hasil uji kualitatif aktivitas lipase pada Rhodamin B

Tabel 1. Indeks zona isolat bakteri LpTK 19

\begin{tabular}{ccc}
\hline \multirow{2}{*}{ Kode Isolat } & \multicolumn{2}{c}{ Indeks Zona (\%) } \\
\cline { 2 - 3 } & 24 jam & 48 jam \\
\hline LpTK 19 & 20.637 & 90.59 \\
\hline
\end{tabular}

\section{Uji Kuantitatif Aktivitas Lipase}

Aktivitas enzim spesifik didefinisikan sebagai kecepatan pengurangan substrat atau kecepatan pembentukan produk pada kondisi optimum (Lehninger. 1990). Uji aktivitas lipolitik kuantitatif dilakukan sebagai uji lanjutan terhadap pengukuran aktivitas lipolitik kualitatif. Hasil pengujian aktivitas lipolitik secara kuantitatif menunjukkan isolat bakteri LpTK 19 memiliki aktivitas lipase yang cukup tinggi.

Tabel 2. Hasil uji aktivitas lipase secara kuantitatif

\begin{tabular}{ccc}
\hline Kode Isolat & Aktivitas $(\mathrm{U} / \mathrm{mL})$ & Kadar Protein $(\mathrm{mg} / \mathrm{mL})$ \\
\hline LpTK 19 & 6.5 & 0.92 \\
\hline
\end{tabular}

Isolat bakteri LpTK 19 memiliki nilai aktivitas lipolitik sebesar 6.5 U/mL dengan kadar protein $0.92 \mathrm{mg} / \mathrm{mL}$ (Tabel 2). Besarnya aktivitas lipase menunjukkan bahwa bakteri dapat menghasilkan enzim yang mampu menghidrolisis triasilgliserol menjadi 


\section{Median Volume 12 Nomor 1 Bulan Februari 2020}

Doi http://doi.org/md.v12i1.371

asam lemak bebas. Nilai aktivitas enzim lipase menunjukkan aktivitas relatif tinggi dibandingkan dengan enzim lipase ekstraseluler yang diektraksi dari sumber lain. Berdasarkan penelitian lain yang dilakukan Kasipah et al. (2013), mendapatkan nilai aktivitas enzim lipase ekstraseluler yang dihasilkan hanya sebesar $4.75 \mathrm{U} / \mathrm{mL}$.

\section{Waktu Optimum Produksi Lipase}

Pengamatan waktu optimum produksi enzim dilakukan berdasarkan 6 variasi waktu inkubasi (Gambar 2).

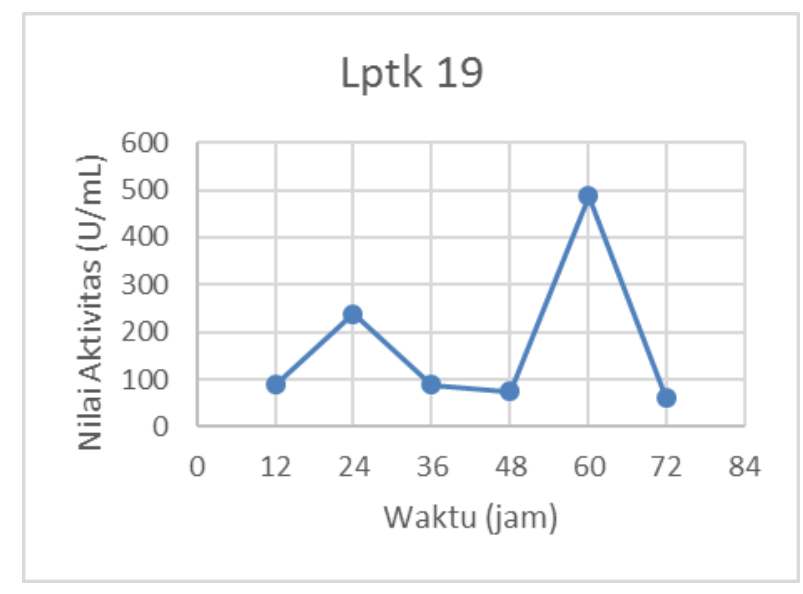

Gambar 2. Aktivitas lipase terhadap waktu produksi

Ekstrak kasar enzim lipase ekstraseluler (crude enzim) diukur dengan metode titrimetri. Ekstrak kasar diperoleh dari hasil separasi kultur sel dan supernatan dengan sentrifugasi kecepatan $10.000 \mathrm{~g}$ selama 15 menit. Tahapan ini digunakan untuk menghindari proses denaturasi protein. Pengujian aktivitas ekstrak kasar lipase dilakukan dengan menggunakan minyak zaitun sebagai substrat, serta buffer fosfat $\mathrm{pH} 8$ dengan suhu inkubasi $37^{\circ} \mathrm{C}$ selama 15 menit. Aktivitas spesifik enzim lipase tertinggi diperoleh pada waktu umur 60 jam yaitu $487.5 \mathrm{U} / \mathrm{mL}$ dan terendah diperoleh pada umur inkubasi 72 jam yaitu $62.5 \mathrm{U} / \mathrm{mL}$.

Hasil penelitian Zusfahair et al. (2010), menunjukkan produksi enzim lipase Acinetobacter sp. mencapai aktivitas lipase maksimumnya pada waktu optimum 18 jam. Penelitian ini menunjukkan bahwa inkubasi 12 jam merupakan fase eksponensial akhir yang memiliki aktivitas enzim tertinggi sebesar $62.50 \mathrm{U} / \mathrm{mL}$. Penelitian lain pada bakteri Azospirillum sp. JG3 menemukan bahwa aktivitas lipase akan terus menurun ketika pertumbuhan telah mencapai fase stasioner (Galliard, 1971). Berkurangnya aktivitas enzim dipengaruhi oleh semakin tingginya akumulasi senyawa inhibitor enzim selama inkubasi. Selain itu penurunan enzim juga dipengaruhi oleh produk samping dari hasil reaksi atau terjadi inaktivasi enzim dengan semakin lama inkubasi (Sonoki dan Ikezawa, 1975). Keberadaan enzim lain dalam enzim kasar sampel yang tidak dapat 
dipisahkan dari lipase juga menjadi penyebab menurunnya aktivitas enzim (Pahoja. et. al.. 2001).

\section{Pengukuran Kadar Protein Enzim Lipase}

Penelitian ini membuktikan bahwa produksi kadar protein tertinggi terjadi pada inkubasi 48 jam sebesar $12.4 \mathrm{mg} / \mathrm{mL}$, sedangkan terendah terdapat pada jam ke-36 dengan nilai protein $0.3 \mathrm{mg} / \mathrm{mL}$ (Gambar 3).

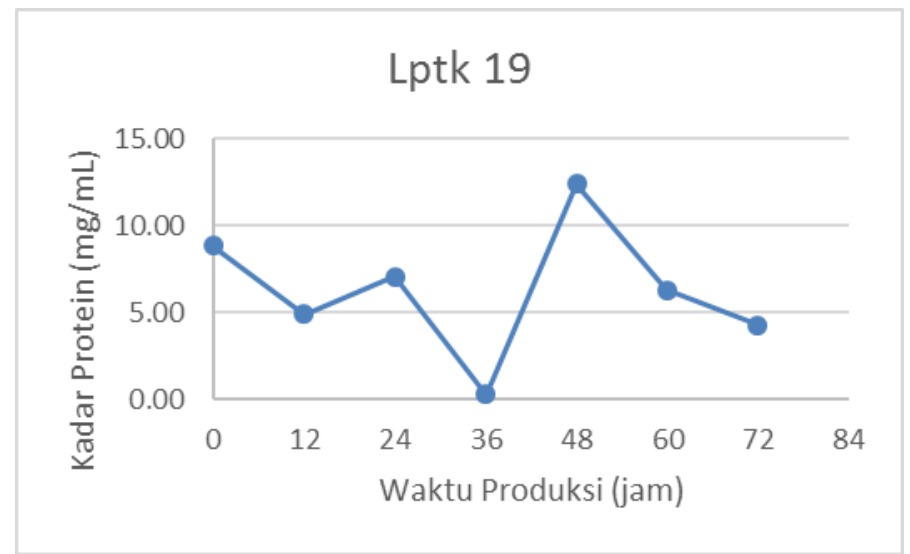

Gambar 3. Pengukuran kadar protein

Tabel 3. Hasil Pengujian Aktivitas Spesifik Enzim Lipase Bakteri LpTK 19

\begin{tabular}{cccccccc}
\hline Isolat & $\begin{array}{c}\text { Waktu } \\
\text { Produksi } \\
(\mathrm{jam})\end{array}$ & $\begin{array}{c}\text { Volume } \\
\text { sampel } \\
(\mathrm{mL})\end{array}$ & $\begin{array}{c}\text { Protein } \\
(\mathrm{mg} / \mathrm{mL})\end{array}$ & $\begin{array}{c}\text { Total } \\
\text { protein } \\
(\mathrm{mg})\end{array}$ & $\begin{array}{c}\text { Aktivitas } \\
(\mathrm{U} / \mathrm{mL})\end{array}$ & $\begin{array}{c}\text { Total } \\
\text { Aktivitas }\end{array}$ & $\begin{array}{c}\text { Aktivitas } \\
\text { Spesifik } \\
(\mathrm{U} / \mathrm{mg})\end{array}$ \\
\hline & 12 & 1.5 & 4.9 & 7.3 & 87.5 & 131.25 & 58.33 \\
& 24 & 1.5 & 7.1 & 10.6 & 237.5 & 356.25 & 158.33 \\
LpTK & 36 & 1.5 & 0.3 & 0.4 & 87.5 & 131.25 & 58.33 \\
19 & 48 & 1.5 & 12.4 & 18.6 & 75 & 112.5 & 50.00 \\
& 60 & 1.5 & 6.3 & 9.4 & 487.5 & 731.25 & 325.00 \\
& 72 & 1.5 & 4.3 & 6.4 & 62.5 & 93.75 & 41.67 \\
\hline
\end{tabular}

Pengukuran kadar protein dalam ekstrak kasar enzim ditentukan menggunakan pereaksi Biuret dan larutan standar BSA (Bovine Serum Albumin) dengan variasi konsentrasi standar yang diukur pada panjang gelombang $480 \mathrm{~nm}$. Kadar protein tertinggi didapatkan pada inkubasi 48 jam sebesar $12.4 \mathrm{mg} / \mathrm{mL}$. Aktivitas enzim tertinggi didapatkan pada inkubasi 60 sebesar $487.5 \mathrm{U} / \mathrm{mL}$ sehingga dapat ditentukan aktivitas spesifik enzim tertinggi sebesar $325.0 \mathrm{U} / \mathrm{mg}$. Penelitian lain menunjukkan kadar protein lipase dari bakteri Azospirillum sp. memiliki jumlah lebih rendah yaitu $4.46 \mathrm{mg} / \mathrm{mL}$ (Lestari et al.. 2009). Penelitian yang mengkaji kadar protein lipase cendawan Aspergillus niger mendapatkan nilai yang jauh lebih kecil yaitu $0.52 \mathrm{mg} / \mathrm{mL}$. Total protein berbeda yang diperoleh diduga disebabkan oleh perbedaan kondisi 
produksi dan jenis bakteri yang digunakan. Total kadar protein yang tinggi dengan nilai aktivitas spesifik rendah menunjukkan bahwa tidak semua protein yang diproduksi teridentifikasi sebagai protein enzim lipase. Hal ini menegaskan bahwa kadar protein tertinggi tidak mutlak memiliki aktivitas enzim lipase yang tinggi.

\section{Identifikasi Mikroskopis dan Biokimia Bakteri}

Hasil uji biokimia dari isolat bakteri lipolitik LpTk 19 yang didapat dari tempe biji karet merupakan golongan bakteri Gram positif yaitu Bacillus sp. (Tabel 4).

Tabel 4. Hasil pengamatan makroskopis. mikroskopis. dan uji biokimia isolat bakteri Lipotitik LpTk 19 Asal Tempe Biji Karet

\begin{tabular}{cc}
\hline Pengamatan/Uji Biokimia & Jenis Isolat \\
Bentuk Koloni & Bulat. Pinggir Rata \\
Permukaan Koloni & Halus Mengkilat \\
Warna Koloni & Putih Kekuningan \\
Gram & + \\
Bentuk Sel & Batang \\
Blood Agar & Non Haemolitik \\
Glukosa & - \\
Laktosa & - \\
Sukrosa & - \\
Maltosa & - \\
Manitol & - \\
TSIA & m/m \\
Indol & - \\
H2S & - \\
Motilitas & - \\
Simon Sitrat & - \\
Oksidase & - \\
Katalase & - \\
Uji Balik & - \\
Species & Bacillus sp. \\
\hline m : Lereng &
\end{tabular}

Keterangan : m/m : Lereng Merah / Dasar Merah

Penelitian yang dilakukan menemukan bahwa tempe biji karet memiliki komponen lemak yang cukup tinggi yaitu mencapai 25\% (Sari, 2018). Hal inilah yang diduga menjadi penyebab tingginya kelimpahan bakteri lipolitik pada sampel tempe biji karet. Bakteri lipolitik LpTk 19 berdasarkan pengujian biokimia dan mikroskopis dapat disimpulkan isolat ini termasuk family Bacillaceae. Analisis uji biokimia dan mikroskopis ini menjadi dasar bahawa isolat ini merupakan Bacillus sp. LpTk 19. 
Tingginya keragaman bakteri pendegradasi lipid terutama golongan Bacillus spp. pada sampel biji karet dipengaruhi juga olah faktor abiotik. Degradasi lipid ditentukan oleh faktor seperti, komposisi kimia hidrokarbon, temperuatur, oksigen, nutrisi, dan derajat keasaman $(\mathrm{pH})$ (Dharmawibawa, 2004). Pada lapisan lipid terdapat sejumlah karbon yang menunjang pertumbuhan mikroba tetapi konsentrasi nitrogen dan fosfor tetap menjadi faktor pembatas.

\section{KESIMPULAN}

Berdasarkan hasil penelitian yang telah dilakukan dapat dinyatakan bahwa enzim lipase dari bakteri lipolitik LpTK19 yang diuji aktifitasnya menunjukkan aktivitas tertinggi pada jam ke-60 sebesar $487.5 \mathrm{U} / \mathrm{mL}$. Kadar protein tertinggi pada jam ke-48 sebesar $12.4 \mathrm{mg} / \mathrm{mL}$, dan aktivitas enzim spesifik tertinggi berada pada jam ke-60 sebesar $325.0 \mathrm{U} / \mathrm{mg}$. Isolat bakteri dari tempe biji karet yang dapat menghasilkan lipase ekstraseluler potensial teridentifikasi sebagai Bacillus sp. LpTk 19

\section{DAFTAR PUSTAKA}

Dahliaty, A., Susanti, R., Haryani, Y. 2012. Skrining Bakteri Lipolitik Dari Air Sungai Siak di Daerah Pelita Pantai Kota Pekanbaru. J. Ind.Che.Acta. 3(1). 2085-0050.

Dharmawibawa, I.D. 2004. Isolasi. Identifikasi dan Uji Kemampuan Bakteri Pengurai Minyak Solar dari Perairan Pelabuhan Benoa Bali. Universitas Udayana. Bali.

Galliard, T. 1971. Enzymic deacylation of lipids in plants. The effects of free fatty acids on the hydrolysis of phospholipids by the lipolytic acyl hydrolase of potato tubers. Eur. J. Biochem. 21: 90-98.

Ghasemi, Y., Rasoul-Amini, S., Kazemi, A., Zarrini, A.G.. Morowvat. M.H.. dan Kargar. M.. 2011. Isolation and Characterization of Some Moderately Halophilic Bacteria with Lipase Activity. Microbiology. 80(4): 483-487.

Gupta, R. N., Gupta dan Rathi, P. 2004. Bacterial Lipases an Overview of Production. Purification and Biochemical Properties. Appl. Microbiology Biotechnology. 64: 763-781.

Joseph, B., Ramtekeand, P.W dan Thomas, G. 2008. Cold active microbial lipases: Some hot issues and recent developments. Biotech Advances. 26: 457-470.

Kasipah, C., Rismayani, S., Ihsanawati dan Nurachman, Z.. 2013. Isolasi danan Karakterisasi Bakteri Penghasil Enzim Lipase Ekstraselulerdari Lumpur Aktif Instalasi Pengolahan Air Limbah Industri Tekstil. Jurnal Ilmiah Arena Tekstil. 28 (1): $1-46$.

Kouker, G dan Jaeger, K.E. 1987. Specific and sensitive plate assay for bacterial lipases. Appl Environ Microbiol. 53(1):211-213.

Lehninger. A.I. 1990. Dasar-dasar Biokimia. Jakarta: Erlangga. 


\section{Median Volume 12 Nomor 1 Bulan Februari 2020}

Doi http://doi.org/md.v12i1.371

Lestari, P., Handayani, S.N dan Oedjijono. 2009. Sifat-Sifat Biokimiawi Ekstrak Kasar Lipase Ekstraseluler Dari Bakteri Azospirillum sp. JG3. Jurnal Molekul. 4(2): 73 82.

Murni, S. W., Kholisoh, S. D., Tanti. D.L., dan Petrissia, E.M.. 2011. Produksi. Karakterisasi. dan Isolasi Lipase dari Aspergillus niger. Prosiding Seminar Nasional Teknik Kimia. Pengembangan Teknologi Kimia untuk Pengolahan Sumber Daya Alam Indonesia. ISSN 1693-4393.

Nur, N. 2015. Telaah Aktivitas Bakteri Penghasil Lipase Yang Berasosiasi Dengan Tempe. Tesis. Bogor: Sekolah Pascasarjana Institut Pertanian Bogor.

Pahoja, V. M., Dahot, M. U. dan Sethar, M. A. 2001. Characteristic Properties of Lipase Crude Extract of Caesalpinia bounducella L. Seeds. J. of Biological Sciences. 1(8): $775-778$.

Pramiadi, D., Yulianti, E., dan Rakhmawati, A. 2014. Isolasi dan uji aktivitas enzim lipase termostabil dari bakteri termofilik pasca erupsi Merapi. Jurnal Sains Dasar. 3(1): $9-19$.

Sari, N.M.R. 2018. Pengaruh Lama Penggantian Air Rendaman Dan Dosis Jamur Komersial Terhadap Kualitas Tempe Biji Karet (Havea Brasilliensis Muell.Arg). Skripsi. Pontianak: Universitas Tanjungpura Fakultas Pertanian.

Sirisha, E., Rajasekar, N. dan Narasu, M.N. 2010. Isolation and Optimization of Lipase Producing Bacteria from Oil Contaminated Soils. Advances in Biological Research. 4 (5): 249-252.

Snellman, E.A., Sullivan, E.R dan Colwell, R.R.. 2002. Purification and properties of the extracellular lipase. LipA. of Acinetobacter sp. RAG-1. FEBS J. 269: 57715779.

Sonoki, S dan Ikezawa, H. 1975. Studies on phospholipase C. from Pseudomonas aureofaciens. Purification and some properties of phospholipase C. Biochemica et Biophysica Acta. 403: 412- 424.

Suhartono, M. T. 1989. Enzim dan Bioteknologi. PAU Bioteknologi IPB. Bogor.

Suryadi, A. 2016. Isolasi Dan Karakterisasi Bakteri Lipolitik Dari Oncom. Skripsi. Bogor: Institut Pertanian Bogor. Fakultas Matematika Dan Ilmu Pengetahuan Alam.

Yin, L dan Chrost, R.J.. 2006. Microbial Enzymatic Activities in AerobicActivated Sludge Model Reactor. Enzyme and Microbial Technology.39: 68-572.

Zusfahair, B., Setyaningtyas, T dan Fatoni, A.. 2010. Isolasi. Pemurnian dan Karakterisasi Lipase Bakteri Hasil Skrining dari Tanah Tempat Pembuangan Akhir (TPA) Gunung Tugel. Jurnal Natur Indonesia. 12(2): 124-129. 